\title{
Comparative evaluation of weed control methods on cowpea (Vigna unguiculata (L.) Walp) production in the savanna Agro- ecological zone of Nigeria
}

\author{
OMISORE J. Kola ${ }^{1}$, ABOYEJI C. Muyiwa ${ }^{2 *}$, DARAMOLA O. F ${ }^{1}$ \\ 1. National Centre for Agricultural Mechanization, P.M.B. 1525, Ilorin, Kwara State, Nigeria. \\ 2. Department of Crop and Soil Science, Landmark University, Omu-Aran, Kwara State, Nigeria. \\ *Corresponding author email: chrismuyiwa@yahoo.com
}

\begin{tabular}{ll}
\hline Paper Information & A B S T R A C T \\
\hline Received: 10 January , 2016 & $\begin{array}{l}\text { Weed competition has the capability of lowering the quality of vegetative } \\
\text { growth as well as the quality and seed yield. A study was conducted during } \\
\text { the } 2014 \text { and } 2015 \text { cropping seasons at the Research farm of the National } \\
\text { Centre for Agricultural Mechanization, Ilorin, to compare some weed } \\
\text { control methods in cowpea production in the savanna agro-ecological zone } \\
\text { of Nigeria. Five weed control methods, Rotary cultivator at 3WAP + Hand } \\
\text { weeding at } 6 \text { WAP, Hand weeding at } 3 \text { and } 6 \text { WAP, Pre-emergence } \\
\text { Published: } 5 \text { May, } 2016\end{array}$ \\
$\begin{array}{l}\text { herbicide + Hand weeding at } 6 \text { WAP, Post-emergence herbicide at } 3 \text { WAP } \\
\text { experiment was laid out in randomized complete block design with three }\end{array}$ \\
$\begin{array}{l}\text { replications. The results were subjected to analysis of variance and } \\
\text { treatment means were separated using the Least Significant Difference } \\
\text { method. The results of this study revealed that, the effect of different weed } \\
\text { control methods employed significantly affected the performance of } \\
\text { cowpea. The presence of weeds in the no weeding control significantly } \\
\text { reduced both the plant height, number of branches crop vigour, total plant } \\
\text { biomass and grain yield. Results also show that, pre- emergence + hoe } \\
\text { weeding at } 6 \text { WAP significantly reduced weed cover score, increased plant } \\
\text { height and number of branches which culminated into increased number of } \\
\text { pods per and grain yield. Hence pre- emergence herbicide + hoe weeding } \\
\text { at } 6 \text { WAP was more effective in controlling weeds in cowpea production in } \\
\text { the study area and can therefore be recommended to cowpea farmers in the } \\
\text { Savanna Agro-Ecological zone of Nigeria. }\end{array}$ \\
\hline C 2016 PSCI Publisher All rights reserved.
\end{tabular}

Key words: Comparison, Weed control methods, Weed cover score, Cowpea and Yield

\section{Introduction}

The need to provide food in the right quantity, quality and at affordable costs remains a priority in most of the developing countries, where the bulk of agricultural production is largely in the hands of peasant farmers Manukwe et al (2012). Constraints faced by this category of farmers include the use of poor plant genetic materials and inadequate protection practices (Williams, 2006).

Weeds are a permanent constraint to crop productivity in agriculture and they are plants which compete for nutrient, space and light and they exert lots of harmful effects by reducing the quality as well as quantity of crop yield if the weed population is left uncontrolled (KavalinusKaite and Bobinas, 2006). Because weeds interfere with mankind's efficient use of the natural environments that have been disturbed, weed control is basic to the use of those environments for food, fiber, shelter and recreation. According to Akobundu (1987) weed control refers to those actions that seek to restrict the spread of weeds and destroy or reduce their population in a given location and it is a required input in most crop production ventures.

Weed management is the ability to manipulate weeds so that they do not seriously interfere with mankind's efficient use of their environment (Akobundu, 1987). He also revealed that in relation to agricultural activities weed management refers to how weeds are manipulated so that they do not interfere with the growth, development and economic yield of crops and animals. Akobundu, (1987) posited that, the major components of weed management are preventive weed control, mechanical weed control, cultural control, biological control and chemical weed control. 
Cowpea (Vigna unguiculata L.) sown in summer season was infested by a number of weed species that competes with the crop right from germination to harvest, affecting the crop yield adversely (Yadav, et al, 1998). Therefore in order to enhance crop yield and its effects on soil fertility, control of weeds during peak periods is very important. Weed density, type of weeds, their persistence and crop management practices determine the magnitude of yield loss (Mohammed et al, 2011). Yield loss in cowpea due to weeds was $12.7-60.0 \%$ ( $\mathrm{Li}$, et al., 2004).

There is no single method to controlling weeds of all forms; different kinds of social, economic and environmental factors influence the choice of control method to be used. Although conventional methods like hand weeding and herbicide application are effective in weed control but they are uneconomical due to higher cost of labour and hazardous effects to the environment (Cheema, et al., 2003). Also in general, herbicides are effective only against some weed species, but results in serious infestation of other weeds. The suggestion that integrated weed management can be useful to provide better weed control measures should further be assessed. In view of these, a study was designed to evaluate different weed control methods under rain-fed cowpea production.

The objective of this study was therefore to compare the effects of several weed control techniques on the performance of cowpea, with a view to recommend an appropriate weed management system for cowpea in this agro ecological zone.

\section{Materials And Methods}

Field experiments were carried out in 2014 and 2015 cropping seasons at the Research farm of the National Centre for Agricultural Mechanization, Ilorin, located on Longitude 4 $30^{\prime}$ 'East and latitude $8^{\circ} 26^{\prime}$ 'North. The common weed species at the experimental site include:- Rottboellia cochinchinensis (Lour), Euphobia hirta, Euphobia heterophila Imperata cylindrica (L.), Cyperus difformis (L.), Oryza barthis A.Chev., Chromolaena odorata (L.,), Ageratum conyzoides (L.) Tridax procumbens, and Cyperus rotundus. Land preparation was done using conventional tillage of ploughing followed by harrowing after about one week interval.

The size of the experimental plot was $27 \times 20 \mathrm{~m}$. Field was thereafter demarcated into plots of $4 \mathrm{~m} \times 4 \mathrm{~m}$. Planting of cowpea seeds were done by hand with a spacing of $75 \mathrm{~cm} \times 15 \mathrm{~cm}$ and 4 seeds were sown per hole at a depth of $2-3 \mathrm{~cm}$ which was later thinned to 2 stands per hole. The cowpea variety planted was Ife brown.

Five treatments which included weeding with rotary cultivator (mounted on a tractor) at $3 \mathrm{WAP}+$ hoe weeding at 6WAP, hoe-weeding at 3 and 6 weeks after planting (WAP), pre-emergence herbicide application (Galex at 5litres/ha) + hoe weeding at $6 \mathrm{WAP}$, post-emergence herbicide application of fusilade ( 2 litres/ha) at $3+3 \mathrm{WAP}+$ Hoe weeding at $6 \mathrm{WAP}$ and a no-weeding check.

Cowpea plants were protected against insect pests by regular spraying with emulsifiable concentrate 250EC of Karate (Lambdacyhalothrin) at two weeks interval before flowering and weekly from flowering to mature fruit stage.

The treatments were laid out in a Randomized Complete Block Design with four replications.

Weed cover scores of the plots were obtained at 3 and 6 WAP just before the weed control methods were applied and the mean recorded. Crop vigour score was obtained at 7WAP, when all weeding techniques had been completed. At maturity 20 plants per plot were taken randomly to study the effects of the weed control methods on plant height, number of branches per plant, number of pods per plant, weight of 1000 seeds, total plant biomass and grain yield in kg per hectare were measured. The results were subjected to analysis of variance and treatment means were separated using the Least Significant Difference method.

\section{Results}

Table 1 shows the weed control methods on plant height and number of branches of cowpea in 2014 and 2015. There was no significant difference in plant height after application of all the weed control methods except on plots treated with preemergence + hoe weeding at $6 \mathrm{WAP}$ which gave a significantly higher plant height in both years and no weeding control which recorded the least plant height.

Higher number of branches was recorded on plots that received pre-emergence + hoe weeding at $6 \mathrm{WAP}$, however, this did not show significant difference from plots that received post-emergence at 3 and $6 \mathrm{WAP}$. Rotary cultivator at $3 \mathrm{WAP}+$ hoe weeding at $6 \mathrm{WAP}$ and hoe weeding at 3 and $6 \mathrm{WAP}$ also gave in similar values for number of branches which was significant when compared with the control.

Weed cover score and crop vigour were significantly affected by different weed control methods (Table 2). Preemergence herbicide + hoe weeding at 6 WAP significantly produced the least weed cover score while the highest weed cover score was obtained at no weeding control. The values obtained from plots that received rotary cultivator at 3 WAP + hoe weeding at $6 \mathrm{WAP}$, hoe weeding at 3 and $6 \mathrm{WAP}$ and post-emergence herbicide at $3 \mathrm{WAP}+$ Hoe weeding at $6 \mathrm{WAP}$ were statistically similar. 
In 2014, hoe weeding at 3 and $6 \mathrm{WAP}$, pre-emergence herbicide + hoe weeding at $6 \mathrm{WAP}$ and post-emergence herbicide at 3 WAP + Hoe weeding at 6 WAP recorded higher values for crop vigour which were statistically similar. In 2015, hoe weeding at 3 and $6 \mathrm{WAP}$ and pre-emergence herbicide + hoe weeding at $6 \mathrm{WAP}$ recorded higher values for crop vigour which are statistically similar. The least crop vigour was observed on no weeding control plots in both years and on plots treated with rotary cultivator at $3 \mathrm{WAP}+$ hoe weeding at $6 \mathrm{WAP}$ in 2015.

Table 1: Effect of Weed Control Techniques on Plant Height and Number of Branches of Cowpea in 2014 and 2015.

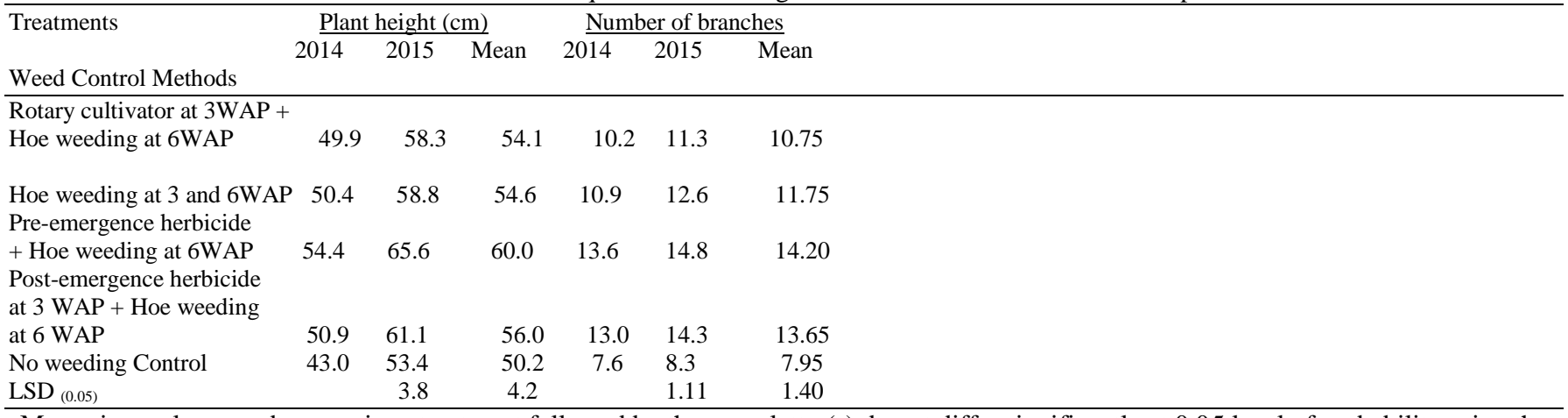

Means in a column under any given treatment followed by the same letter(s) do not differ significantly at 0.05 level of probability using the Least Significant difference (LSD).

Weed score ratings: $\quad 5=\quad$ extremely weedy plot

$1=\quad$ virtually no weed.

Table 2: Effect of Weed Control Techniques on Weed Cover Score and Crop Vigour of Cowpea in 2014 and 2015.

\begin{tabular}{|c|c|c|c|c|c|c|}
\hline \multirow[t]{2}{*}{ Treatments } & \multicolumn{3}{|c|}{ Weed cover score } & \multicolumn{3}{|c|}{ Crop vigour } \\
\hline & 2014 & 2015 & Mean & 2014 & 2015 & Mean \\
\hline \multicolumn{7}{|l|}{ Weed Control Methods } \\
\hline $\begin{array}{l}\text { Rotary cultivator at } 3 \mathrm{WAP}+ \\
\text { Hoe weeding at } 6 \mathrm{WAP}\end{array}$ & 1.9 & 2.3 & 2.1 & 3.1 & 3.5 & 3.30 \\
\hline $\begin{array}{l}\text { Hoe weeding at } 3 \text { and } 6 \mathrm{WAP} \\
\text { Pre-emergence herbicide }\end{array}$ & 1.4 & 1.9 & 1.55 & 4.0 & 4.2 & 4.10 \\
\hline $\begin{array}{l}+ \text { Hoe weeding at } 6 \mathrm{WAP} \\
\text { Post-emergence herbicide }\end{array}$ & 0.6 & 0.7 & 0.65 & 4.5 & 4.6 & 4.55 \\
\hline $\begin{array}{l}3 \mathrm{WAP}+\text { Hoe weeding } \\
\text { at } 6 \mathrm{WAP}\end{array}$ & 1.3 & 8 & & 3.5 & 3.9 & 3.70 \\
\hline No weeding Control & 3.5 & 4.6 & 4.05 & 2.8 & 3.2 & 3.00 \\
\hline $\operatorname{LSD}_{(0.05)}$ & & 0.9 & & $6^{2.0}$ & 0.6 & 0.4 \\
\hline
\end{tabular}

Means in a column under any given treatment followed by the same letter(s) do not differ significantly at 0.05 level of probability using the Least Significant difference (LSD).

Weed score ratings:5=extremely weedy plot $1=\quad$ virtually no weed.

Crop vigour ratings: 5 =Very healthy plants. $1=$ Weak Plants

Effects of weed control methods on Number of pods/plant and 1000 seed weight in 2014 and 2015 are as shown in Table 3. Maximum number of pods per plant was recorded with pre-emergence herbicide + hoe weeding at 6 WAP and postemergence herbicide at 3 and 6 WAP. Similarly, rotary cultivator + hoe weeding at 6 WAP and hoe weeding at 3 and 6 WAP recorded non- significant values for number of pods per plant which was significantly different from the lowest mean number of pods per plant recorded from the control.

In both years, pre-emergence herbicide + hoe weeding at 6 WAP plots recorded higher values for 1000 seed weight although not significant with other weed control methods.

Table 4 shows the effect of weed control techniques on total plant biomass and grain yield of cowpea in 2014 and 2015. Higher total plant biomass was recorded on plots that received pre-emergence herbicide + hoe weeding at 6 WAP which was similar to those obtained on plots that received post-emergence herbicide at 3 and 6 WAP. However, these values were significantly higher than that recorded in other weed control methods. The control gave the least value for total plant biomass. 
In both years, grain yield was highest on plots that received pre-emergence herbicide + hoe weeding at 6 WAP which was closely followed by post-emergence herbicide at 3 and 6 WAP. These values were significantly different from those values recorded on the control plots.

Table 3: Effect of Weed Control Techniques on Number of Pods/Plant and 1000 Seed weight of cowpea in 2014 and 2015.

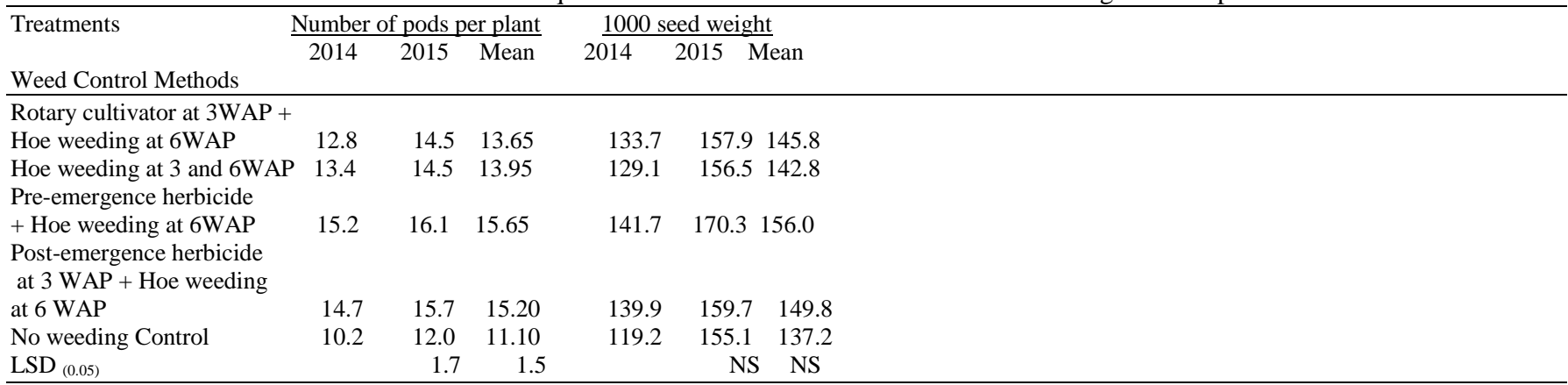

Means in a column under any given treatment followed by the same letter(s) do not differ significantly at 0.05 level of probability using the Least Significant difference (LSD).

$$
\text { N.S = Not significant }
$$

Table 4: Effect of Weed Control Techniques on Total Plant Biomass and Grain Yield of cowpea in 2014 and 2015.

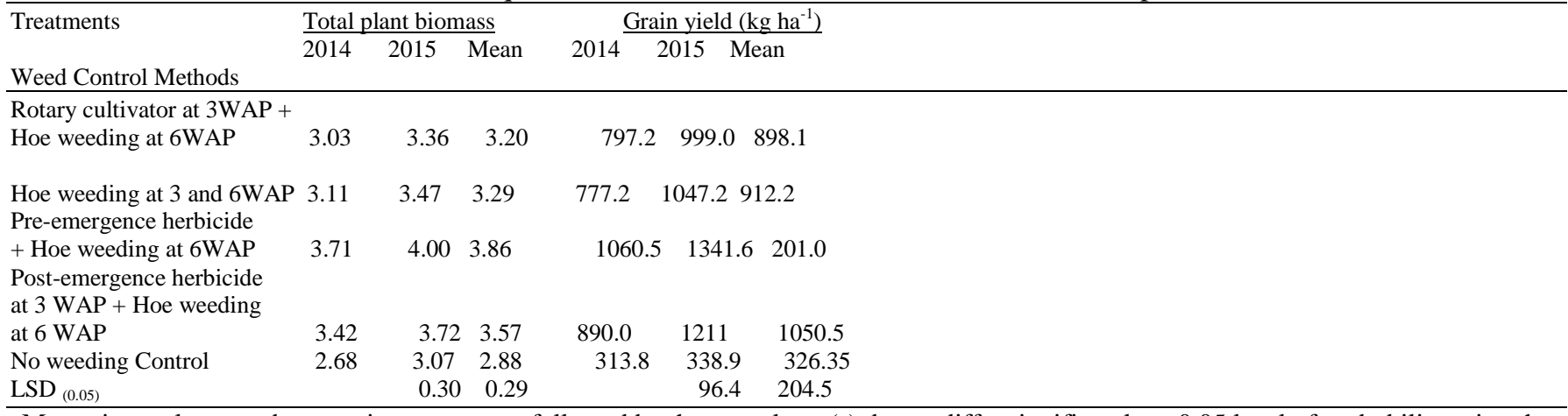

Means in a column under any given treatment followed by the same letter(s) do not differ significantly at 0.05 level of probability using the Least Significant difference (LSD).

\section{Discussion}

Manual hoe weeding is prevalent in Nigeria as many farmers cannot afford the conventional means of weed control. Majority of the cowpea farmers in Nigeria are peasant farmers who practice cultural means of weed control and this greatly affects the total area in which each farmer can cover. Availability of labour has also been identified to be one of the factors militating against cowpea production in Nigeria.

Weeds competes with plants generally and if not controlled may lead to total yield loss. Weeds are hardy and vigorous in growth habit, they outgrow target crops and consume large amount of environmental resources.

Controlling weeds may involve wide range of techniques which depends on the resources available to the farmers, the type of weeds and nature or morphology of the crop planted.

life.

Legumes are weak competitors for environmental resources when the weeds are not controlled at the early stage of

The results of this study revealed that, the effect of different weed control methods employed significantly affected the performance of cowpea. The presence of weeds in the no weeding control significantly reduced both the plant height and number of branches. This could be as a result of competition for nutrients and water. Weeds controlled at early stage of development increased plant height and number of branches produced. This could be attributed to efficient utilization of nutrients and water by cowpea plants as a result of reduced weed competition. This was most evident on plots that were treated with pre-emergence herbicide + hoe weeding at 6 WAP.

Plant height and number of branches on plots treated with Post-emergence herbicide at 3 WAP + hoe weeding at 6 WAP closely followed pre-emergence herbicide + hoe weeding at 6 WAP. This could be as a result of minimal soil disturbance experienced on those plots. 
The results also revealed that all the weed control methods significantly $(\mathrm{P}<0.05)$ decreased weed population.

Weed cover score were higher on no weeding control plot and least on pre-emergence + hoe weeding at 6 WAP and post- emergence + hoe weeding at 6 WAP. This may probably be as a result early weed control and the ability of cowpea to suppress and smother weeds due to early canopy cover which shaded off the weeds and depriving them of growth factors (Imoleame, 2004). Increased weed cover score on rotary cultivator at $3 \mathrm{WAP}+$ hoe weeding at $6 \mathrm{WAP}$ and hoe weeding at 3 and 6 WAP could be as a result of soil disturbance which exposed weed seeds for germination.

Increase in weed cover score resulted in reduced crop vigour and this was evident on no weeding control. Plots that received pre-emergence herbicide + hoe weeding at $6 \mathrm{WAP}$ produced higher values for crop vigour which was similar to hoe weeding at 3 and 6 WAP when compared with other weed control methods and the no weeding control.

matter in plants is made up of organic matter and is dependent on the amount of solar energy receipt which may be directly correlated to the crop vigour and most times the yield. Total plant biomass, number of pods per plant, 1000 seed weight and grain yield were also affected by different weed control methods. Plots with pre-emergence herbicide + hoe weeding at 6WAP produced higher values for total plant biomass, number of pods per plant, 1000 seed weight and grain yield which could be linked with taller plant height and more number of branches. Taller plant height and more number of branches could provide the plants with greater reception of light which encouraged photosynthetic process which is a prerequisite to total plant biomass, number of pods per plant, 1000 seed weight and grain yield. It could also be as a result of reduced competition which enable cowpea plant to absorb more nutrients and water from the soil, carry out effective photosynthetic process and able to store photosynthates.

Comparatively less efficiency of rotary cultivator at $3 \mathrm{WAP}+$ hoe weeding at $6 \mathrm{WAP}$ and hoe weeding at 3 and 6 WAP might be due to competition between weeds that re-emerged after each weeding operation which exposed more weed seeds that germinates and competes with crop plants for plant nutrients resulting in poor crop growth and hence minimum plant biomass and grain yield. Reduction in yield as a result of use of rotary cultivator could also be attributed to nutrient leaching caused by decreased in soil compaction and possibly due to increase in number of plant death.

\section{Conclusion}

This study compared different weed control methods in cowpea production. The result showed that pre- emergence + hoe weeding at 6 WAP significantly reduced weed cover score, increased plant height and number of branches which culminated into increased number of pods per plant and grain yield. Hence pre- emergence herbicide + hoe weeding at 6 WAP was more effective in controlling weeds in cowpea production in the study area and can therefore be recommended to cowpea farmers in the Savanna Agro-Ecological Zone of Nigeria.

\section{References}

Akobundu IO. 1987. Weed management in: Weed Science in the tropics, Principle and Practices. "A Wiley-Interscience publication".Printed in Great Britain by Page Bros. (Norwich) ltd. Pp 71-73.

Cheema ZA, Hussain S, Khaliq A. 2003. Efficacy of sorgaab in combination with allelopatic water Extracts and reduced rate of pendimethalin for weed control in mungbean. Industrial J. of Plant Sci., 2: 21-25.

Imoloame EO.2004. Effects of seed rate and sowing method on weed infestation, growth and yield of sesame(Sesamum indicum L) in the semi arid zone of Nigeria M.Sc. Dissertation University of Maiduguri, p. 48.

KavalinusKaite D, Bobinas, C. 2006. Determination of weed composition critical period in red bat. Agronomic Res., 4: 217-220.

Li R, Guidong Z, Yumei Z, Zhanzhi X. 2004. Damage loss and control technology of weeds in cowpea field. Weed Sci., 2: 25-36.

Madukwe DK, Ogbuehi HC, Onuh MO.2012. Effects of weed control methods on growth and yield of cowpea (Vigna unguiculata (L) Walp) inOwerri. American Erasian J. Agric. And Environmental Sc. 12 (11). 1426- 1430.

Muhammad AM, Faisal Z, Muhammad RA, Muhammad R, Umarah A, Khalid M, Raza SH. 2012. Weed biomass and economic yield of wheat (Triticum aestivum) as influenced by chemical weed control under rainfed conditions. African Journal of Biotechnology Vol. 11(7), pp. 1567-1573.

Williams MM. 2006. Planting date influences critical period of weed control in sweet corn. Weed Sci., 54: 928-933.

Yadev BD, Joon RK, Singh JV. 1998. Contribution of production factors on growth and seed yield of cowpea under rain-fed conditions. Forage Res., 24: 157168. 